\title{
Irish Bastards: Celia de Fréine and Merriman's The Midnight Court/Cúirt an Mheán Oíche
}

\section{Briain Ó Conchubhair}

\section{Q OpenEdition \\ 1 Journals}

\section{Electronic version}

URL: http://journals.openedition.org/etudesirlandaises/5005

DOI: 10.4000/etudesirlandaises.5005

ISSN: 2259-8863

\section{Publisher}

Presses universitaires de Rennes

\section{Printed version}

Date of publication: 30 November 2016

Number of pages: $105-118$

ISBN: 978-2-7535-5358-3

ISSN: 0183-973X

\section{Electronic reference}

Briain Ó Conchubhair, «Irish Bastards: Celia de Fréine and Merriman's The Midnight Court/Cúirt an Mheán Oíche », Études irlandaises [Online], 41-2 | 2016, Online since 30 November 2018, connection on 20 April 2019. URL : http://journals.openedition.org/etudesirlandaises/5005 ; DOI : 10.4000/ etudesirlandaises.5005 


\title{
Irish Bastards: Celia de Fréine and Merriman's The Midnight Court/Cúirt an Mheán Oíche
}

\author{
Briain Ó CoNCHubHaIR \\ Notre-Dame University
}

Abstract

This article examines Celia de Fréine's re-imagining of Brian Merriman's canonic text The Midnight Court/Cúirt an Mheán Oíche. Through textual and contextual analysis of specific extracts of the texts, the article illustrates how de Fréine's version challenges audiences to consider their participation in the social conditions of contemporary marriage, relationships and sexual practices for young women in contemporary Ireland. To this end she draws on Kevin Myers' "Mother of Bastards" article to highlight the misogyny experienced by unmarried mothers in Ireland.

Keywords: De Fréine, Merriman, Cúirt an Mheán Oíche, The Midnight Court, sexual practices, gender, misogyny.

\section{Résumé}

Cet article sintéresse à la réinterprétation théatrale de The Midnight Court/Cuiirt an Mheán Oiche, texte canonique de Brian Merriman. Dans la version contemporaine, Celia de Fréine pousse le public à sinterroger sur la condition contemporaine des enfants nés en dehors des liens du mariage en Irlande et à examiner la responsabilité de chacun dans la manière dont sont considérées les relations et pratiques sexuelles des jeunes femmes ainsi que l'institution du mariage. À cette fin, elle s'inspire d'un article polémique du journaliste Kevin Myers pour souligner la misogynie dont sont victimes les filles mères.

Mots clés : De Fréine, Merriman, Cüirt an Mhean Oiche, The Midnight Court, pratiques sexuelles, genre, misogynie.

Celia de Fréine, born in Newtownards, County Down, is an established poet with eight published collections of poetry in English and Irish ${ }^{1}$. Widely anthologized and translated, her awards include the Patrick Kavanagh Award, the British Comparative Literature Association Translation Award and the Gradam Litríochta Chló Iar-Chonnacht. Her dramatic work in English and in Irish includes operatic

1. A Lesson in Can't, 2014; Blood Debts, 2014; Cuir Amach seo Dom: Riddle me this, 2014; Aibitir Aoise : Alphabet of an Age, 2011; Imram : odyssey, 2010; Scarecrows at Newtownards, 2005; Fiacha Fola, 2004; Faoi Chabaiistí is Ríonacha, 2001. 
and cinematic texts as well as scripts for TG4's soap-opera, Ros na Rún (1997-99) as well as six published plays, three of which have been translated into English ${ }^{2}$. Focusing on her provocative re-imaginings of Brian Merriman's canonical eighteenth-century text Cúirt an Mhean Oiche / The Midnight Court, her trilogy is as much a response and riposte to Celtic Tiger Ireland and social and sexual attitudes that seeks to discriminate against the vulnerable in society, as it is a refashioning and recalibrating of Merriman's eighteenth-century long dramatic poem.

De Fréine's drama is steadfastly and confidently rooted in contemporary social, ethical, and moral issues. Her plays, including her adaptations - and even more so in her Irish-language plays which examine detention centres, "direct provision", refuges, war zones and attempted suicide - leave unanswered social questions concerning sexuality and treatment of women and emigrants. They raise doubts about the value of whether examining, debating, and discussing or relying on the established system will actually achieve anything or even alter society's habits and behaviours. Such issues, these plays suggest, cannot be solved by introspection and call instead for action and engagement. Her willingness to confront such major concerns and her Shavian engagement with social issues not only marks de Fréine out but it places her in a direct line with Maireád Ní Ghráda, whose 1964 play An Triail boldly and courageously addressed the treatment of single mothers and the Magdalen Laundries. It also links her with Pádraig Ó Conaire's earlier Bairbre Ruadh, an Ibsen-type play that examined arranged marriages between younger women and older men ${ }^{3}$. It is the direct non-apologetic challenge her plays issue to audiences and their forthright discussion of individual responsibility for society's ills that distinguishes her plays from those of many of her contemporaries. The plight of the title is as much the characters' collective plight as it is society's and the feelings it intentionally provokes among the audience.

2. Celia de Fréine, “Soap for TnaG: Writing Ros na Rún,” New Hibernia Review, 3:1, Spring, 1999, p. 142-148. In a 2014 interview with Lia Mills, "Hidden Ireland", Dublin Review of Books, Issue 61, November 2014, her output consisted of "Eight volumes of poetry, six published plays (and others produced in various settings), a libretto, prizewinning screenplays and film-poems, short stories in English - all in thirteen years. This autumn sees the publication of these two collections, five new plays in various stages of production and the installation with Mark McKee”. See: [http://www.drb.ielessays/hidden-irelands\#sthash.LeHv9xKA.dpuf] (accessed 26 March 2016). In 2015 Umbrella Theatre Company staged de Fréine’s "Seamstress", inspired by Kasimir Markievicz's “"The Artist's Wife", and also "Stamen”, inspired by Mainie Jellett's "Single Element”, as part of Sixteen 10 Minute Plays at the National Gallery of Ireland. Umbrella also staged "Katie \& Beth", two short plays by Lia Mills and Celia De Fréine exploring the lives of fictional characters against the backdrop of real events in Dublin in 1916 .

3. In the course of an interview in the Dublin Review of Books (Issue 79, June 2016) with Lia Mills she explains that her play Safe, originally written in Irish but performed in English in October 2014 by the Umbrella Theatre Company, derived from the Pavilion Playwrights (established by Conall Morrison in 2011) "is written in homage to Mairéad Ní Ghráda, whose play An Triail premiered fifty years ago this autumn. An Triail tells the story of a young unmarried mother who, rejected by society, kills her child and then herself. I wanted to revisit this theme and explore the changes in Irish society to women's reproductive health". See more at: [http://www.drb.ie/ essays/hidden-irelands\#sthash.LeHv9xKA.dpuf]. 
De Fréine may write in Irish and English, but the canvas on which she paints extends far beyond the shores of Ireland. She is very much an international playwright. Shaw's belief that the art of the dramatic poet knows no patriotism is relevant for de Fréine. Her multi-genre body of work - regardless of genre and language - speaks directly to an audience and addresses issues wider than those of the Republic of Ireland. Her medium may be Irish and HibernoEnglish, but her substantial body of dramatic work, both published and unpublished, not only speaks to, but resonates with audiences far beyond the coastal confines of her native island. Indeed, de Fréine's body of work demonstrates her refusal to be bound by conventional notions of theatrical form and theme. For all the breadth of her creative interests - poetic, cinematic, operatic, dramatic de Fréine remains something of a cult figure rather than a mainstream writer in Irish or in English. In part this stems from her refusal to occupy an easily categorized bilingual Irish-English fusion niche writing about folklore and sociolinguistic impact and hybridity, but also from her disinclination to conform to the system's expectations of what bilingual playwrights write about - cultural and linguistic conflict. Her heritage exerts a gravitational force on her drama, but overt references are rare.

De Fréine, more fortunate than most Irish-language theatre-makers, developed and cultivated a link with Amharclann de hÍde, a professional Irish-language theatre company, founded in Dublin in 1992 (closed in 2001). With no permanent venue, Amharclann de hÍde produced predominantly original plays but also, on occasion, some translated classic plays in various theatres and venues in the capital city ${ }^{4}$. In collaboration with Aisling Ghéar (established in Belfast in 1997), the Dublin-based theatre company Amharclann de hÍde staged de Fréine's play Nára Turas é in Aistear (That the journey may not be in vain) on 2 May 2000 at the New Theatre in Dublin's Temple Bar ${ }^{5}$. Aisling Ghéar also produced Anraith Neantóga, de Fréine's futuristic play where warfare is endemic and two women survive on the edges of the fight zone although both are in denial of their realities. The play opened on 22 September 2004 at Belfast's Cultúrlann McAdam/Ó Fiach with Dorothy Cotter, Máire Hastings, Barry Barnes, and Tony Devlin in the cast and directed by Bríd Ó Gallchóir. This play’s production resulted from close col-

4. Séamas Mac Annaidh, An Druma Mór, 2000; Alan Titley, An Ghráin agus an Ghruaim, 1999; Brian Ó Riagáin, Buille an Phice, 1997; Ceacht Houdini, Michael Harding (1994); Éilís Ní Dhuibhne, Dún na mBan Tri Thine, 1994; Liam Ó Muirthile, Fear an Tae, 1999; Liam Ó Muirthile, Liodán na hAbhann, 1999; Seán McCarthy, Mallachtai Muintire, 1993; Éilís Ní Dhuibhne, Milseog an tSambraidh, 1997; Tom Sailí Ó Flaithearta, Pósadh an Tincéara, 1996; Liam Ó Muirthile, “Tine Chnámh”, Dir. Michael Scott, 1993.

5. Located at 43 East Essex Street, Temple Bar, Dublin 2. Essex Street West was formerly named Smock Alley, site of the famous Smock Alley Theatre. Amharclann de hÍde subsequently brought the production to Galway. Cast members included Lesley Conroy, Bríd McCarthy, Brendan Murray, Gavin O’Connor, and Brian Thunder. Director Bríd Ó Gallchóir; Set Katherine Sankey; Lighting Aedin Cosgrove; Costumes Moira Tierney; Music and Sound by J.J. Vernon. 
laboration between de Fréine and Aisling Ghéar's writing workshop led by Artistic Director, Bríd Ó Gallchóir.

The staging of these two de Fréine plays, both accorded professional productions, occurred not only while Ireland enjoyed the Celtic Tiger economic boom but at a time that was, in hindsight, possibly a golden era for Irish-language theatre. Amharclann de hÍde, Aisling Ghéar, and An Taibhdhearc, the Irish-language National Theatre based in Galway, provided opportunities, options, and venues for Irish-language writers and for Irish-language women writers who were previously conspicuously absent from the tradition: Maireád Ní Ghráda was the exception that proved the rule. Tellingly perhaps, she also benefitted from a vital link with the Dublin-based An Damer. Irish-language productions at the Abbey Theatre, on the main stage or at the Peacock (the formerly proposed dedicated Irish-language stage) are as scarce, if not more scarce, than plays by Irish women over the past twenty-five years. "The Abbey Theatre, or Amharclann na Mainistreach, has mounted just one full-length Irish-language production in the past 15 years (Aodh Ó Dómhnaill's Idir an Dá Shúil in December (2010)) and you'd have to go back to the 1960s to discover the last in-house Irish-language production that graced its main stage ${ }^{6 "}$.

In such circumstances, de Fréine is again distinguished in having had her work chosen for an Abbey workshop during this period. The formation of Amharclann de hÍde in Dublin, and Aisling Ghéar in Belfast, provided a coherent structure, infrastructure, and network for new plays to be read, work-shopped, produced, and staged. Prior to this development, women as Irish-language playwrights, directors, or producers, other than translators, were scarce: Áine Nic Giolla Bhríde (Cor na Cinniúna 1961), Maireád Ní Ghráda and Siobhán Ní Shúilleabháin being the main dramatists who carried the female flag on stage ${ }^{7}$. Historians of Irish theatre may consider this period an artistic acme. De Fréine, therefore, came to theatre at an opportune time: women had acquired positions of influence in the decision-making processes, the cultural and economic climate was not unfavourable. The presence of Ní Ghallchóir at Amharclann de hÍde, Hynes at the Abbey, and subsequently Ó Gallchóir at Aisling Ghéar allowed for a flowering of Irish-language drama, and, in particular, a bourgeoning of drama by Irish women

6. Caomhan Keane, "Irish language theatre - is it time to stage a revival?", Irish Times, 13 June 2011.

7. In the 34-year period from 1975 to 2009, women accounted for 26 new plays in Irish, some 23\%. Between 1994 and 2004, these two companies with Bríd Ó Gallchóir as the common denominator - Aisling Ghéar's Artistic Director and former Artistic Director with Amharclann de hÍde - produced and toured eight new Irish-language plays by six women: Siobhán Ní Shúilleabháin's Is Tú Mo Mhac, An Taibhdhearc, 1990; Éilís Ní Dhuibhne's Dún na mBan Trí Thine, Amharclann de hÍde, 1994 and Milseog an tSamhraidh, Amharclann de hÍde, 1997; Biddy Jenkinson's O Rajerum, Aisling Ghéar, 1999 and Mise, Subhó agus Maccó, Aisling Ghéar, 2000; Nuala Nic an Iomaire's An tUisceadán, Taibhdhearc \& Andrews' Lane, 2001; Celia de Fréine's Anraith Neantóige, 2004; and Caitríona Ní Chonaola’s Incubus, 2005. Even in the heyday of An Comhar Drámaíochta, it is unlikely that such a high level of activity was attained and certainly not by female authors and directors. 
and plays providing a framework for an intervention in a manner not always offered through the traditional channels. De Fréine is at the heart of that cultural configuration ${ }^{8}$. Nevertheless, in 2010 de Fréine stressed in her article "Women Playwrights, Whither?” that “...while most theatre-goers are women, all major theatres nurture the talent of male playwrights. Women have seldom moved into positions of power in theatre as they have in publishing, editing and translating; where they have, there is no evidence that this has had any consequences in terms of nurturing women playwrights to date ${ }^{9}$.

Celia de Fréine is perhaps distinct among the plethora of translators, interpreters, and adaptors who have reimagined the eighteenth-century Irish-language poem Cuiirt an Mheán Oiche/The Midnight Court, attributed to Brian Merriman, the Clare poet, scribe, and scholar, into English, German, Esperanto, French and most recently, Japanese. The poem has been recorded for commercial records, adapted for radio and opera, and interpreted by stage and graphic artists across the globe. De Fréine distinguishes herself by being one of just two women to adapt the 1,026-line Irish-language poem for stage. In 1982, when the Dublin Shakespeare Society (founded in 1907), performed her translated adaptation at the Studio North Great George's Street Dublin ${ }^{10}$ she became the first person to produce three print adaptations/responses to this classic and iconic text ${ }^{11}$. Given the centrality of women, women's perspectives, societal attitudes towards sexual behaviours including monogamy, pre-marital sex, non-marital sex, clerical celibacy and sexual relations between partners of disparate ages, and gender issues in the original eighteenth-century text, as well as the powerful role played by Aoibheall, queen of the Munster fairy-folk, female writers' traditional reluctance to engage with it is nothing if not remarkable. Less remarkable is that de Fréine would gravitate towards this canonical text given how prominently historical lite-

8. Among the few, if not only, male playwrights to emerge in this period is Aodh Ó Domhnaill, closely associated as writer and actor with the long-established Dublin amateur group Aisteoirí Bulfin. In a recent interview in the Irish Times he cited the poor quality of productions rather than acting or scripts for the plight of Irish-language drama. "Tá aisteoirí againn atá chomh maith le héinne eile ach tá easpa scríbhneoirí agus léiritheoirí ann. Is minic gur sa chaighdeán léirithe a bhíonn na laigí is mó i ndrámaí Gaeilge agus sin an fáth gur thugamar isteach léiritheoir gairmiúil, Barry Byrnes, do LaraeDó." See Seán Tadhg Ó Gairbhí, "Blazing Saddles na Gaeilge", Irish Times, 4 Nollaig 2013. For the development of plays by Irish women, see Patrick Lonergan, [http://patricklonergan.wordpress.com/tag/irish-women-dramatists/] (accessed 7 December 2013).

9. De Fréine, "Women Playwrights, Whither?", Creation, Publishing, and Criticism: The Advance of Women's Writing. María Xesús Nogueira, Laura Lojo, Manuela Palacios, eds., New York, Peter Lang, 2010, p. 196.

10. Directed by Helen Byrne. Written by Celia Hart (Celia de Fréine). Staged at the Studio, Dublin. The Shakespeare Society has since relocated to Club na Múinteoirí, 36 Parnell Square, Dublin. This collaboration was revived in 2007, when the same company again staged a revised version of the play at Theatre 36 as part of their centenary celebrations. In 2009, in association with Opera Ireland, Living Opera presented a showcase performance of the opera The Earl of Kildare, composed by Fergus Johnston, for which de Fréine wrote the English-language libretto.

11. Siobhán McKenna's dramatic adaptation would appear on the Peacock Stage at the Abbey in October 1984. 
rature featured in her early world. "When I first began writing plays, I based my work on Irish myths: The Courting of Emer' ${ }^{12}$ (1985) and Diarmuid agus Grainne ${ }^{13}$ (1986); and on women in history: I Have Seen the Stars (1988); Holloway, 1918 (1989); and Girls in Silk Kimonos (1991). By 1997, however, my plays had begun to address contemporary issues ${ }^{14}$."

De Freine's engagement with Merriman dates back to 1982 when the Dublin Shakespeare Society produced her translation and dramatisation of Brian Merriman's poem as The Midnight Court as part of their centenary celebrations. Subsequently De Fréine's creative response to Cúirt an Mheán Oíche / The Midnight Court expanded to Lorg Merriman, a trilogy of plays that comprises (1) Desire: Meanmarc; (2) Brian Merriman's The Midnight Court, and (3) Plight: Cruachás. Published by Arlen House in 2012, Desire: Meanmarc forms Part I of a threepart engagement and reimagines Brian Merriman's social network and personal life immediately before he composed his poetic masterpiece. Written in 2009, Desire: Meanmarc received the 2010 Duais an Oireachtais do Dhráma Ilghniomh (Oireachtas Award for multi-act play), before the author subsequently revised and translated it into English as Part I of her Lorg Merriman (Merriman's Mark/Footprint) project ${ }^{15}$. The text performed by the Dublin Shakespeare Society in 1982

12. "Tochmarc Emire, the Wooing of Emer", is an Ulster Cycle tale detailing the courtship and marriage of Emer and Cú Chulainn.

13. Tóraigheacht Dhiarmada agus Ghráinne / The Pursuit of Diarmuid and Gráinne, is a Fenian tale involving a love triangle between the aged great warrior Fionn, the beautiful Grainne, and the younger and more attractive Diarmuid na mBan. Zoë Seaton produced a play in English also based on the ancient text, adapted by Zoë Seaton and Bríona Corrigan for Big Telly in 1999. Jean Butler and Colin Dunne starred in Dancing on Dangerous Ground, a Riverdance-type Irish dance show, which premiered at the Theatre Royal Drury Lane, London, in 1999. Paul Mercier and The Passion Machine, in association with John McColgan's Abhann Productions, also produced a version in 2001, "part Quentin Tarantino, with its gangster-land style, and part Moulin Rouge, with its dancing men” (Irish Independent, 2 June 2002). Mícheál Mac Liammóir produced the classic adaptation at the Gate and An Taibhdhearc in 1928. See Richard Allen Cave "The Dangers and Difficulties of Dramatising the Lives of Deirdre and Grania" $n$ Perspectives of Irish Drama and Theatre, edited by M. D. Savage (ed.), Barnes and Noble, 1991, p. 1-16.

14. De Fréine, "Women Playwrights, Whither?" art. cit., p. 192.

15. The Abbey Theatre commissioned Casadh, de Fréine's short play and provided a rehearsed reading at the Peacock Theatre on 21 October 2009, and subsequently at An Chultúrlann, as part of the Gach Áit Eile a short play reading series. Other plays in the 2009 series included Cú Dé by Dave Duggan (cast: Denis Conway, Mary Louise McCarthy), Ar Dheireadh by Aodh Ó Domhnaill (cast: Siobhán O’Kelly, Don Wycherley), and Casadh (cast: Josie Chóilí Óg Ó Cualáin, Mairéad Conneely). The three plays were staged in An Chultúrlann as part of the Belfast Festival at Queens University on 24 October. Paul Mercier directed the "Gach Áit Eile” production. The plays were also produced at Oireachtas na Samhna, Letterkenny, 29 October. De Fréine casts doubt on the overall value of such readings in which emphasis is placed on the performance rather than script development: "Working with a director and actors is generally helpful in developing a script, but where these readings were concerned, the rehearsal period was short and we had to focus on preparing for the performance rather than on script development." See de Fréine, "Women Playwrights, Whither?"n art. cit. "Gach Áit Eile” is the phrase used on Irish mail-boxes as equivalent to "All Other Places." Regarding "Gach Áit Eile," Aideen Howard is quoted as saying "This was an interesting process for us... as it allowed us to connect with the writers that were out there already and to reconnect with an audience who we haven't been engaged with for seven years". The Abbey then approached writers who were writing in the language, but not necessarily for the stage, through 
became the basis for the second part of this innovative trilogy. Plight: Cruachás (Arlen House, 2012), written in 2005 to celebrate the two-hundredth anniversary of Merriman's death in 1805 and first staged in Irish by Aisteoirí Bulfin in the Brehon Hotel, Killarney, Kerry, on 1 November 2014 as part of the Oireachtas Literary Festival, is the trilogy's third and final instalment. The play considers the implications of the imaginary court reconvened in the second decade of twentyfirst century Ireland and asks which sexual mores might be offered up to an extraterrestrial deity for consideration ${ }^{16}$. The play's premise is an ancient, but recently discovered, tribe, living on the margins of Irish society with its own indigenous customs and traditions, removed from mainstream Irish culture. To protect its youth from the dangers that mainstream society poses, these parents encourage their offspring to marry within the tribe while still in their teens. This play examines the problems such young people would face.

Cuirt an Mhean Oiche / The Midnight Court is a canonical eighteenth-century text widely considered to be one of the greatest comic Irish poems in either English or Irish. Despite its simple linear storyline, Merriman's poem addresses a wide range of themes, from its satirical treatment of sexuality to its biting social commentary. Banned as a translation in the Irish Free State for obscenity, its famously frank and bawdy descriptions of human sexuality have delighted and enraged readers and listeners for centuries. "The good drama survives", according to David Mamet, "because it appeals not to the fashion of the moment, but to the problems both universal and eternal, as they are insoluble. To find beauty in the sad, hope in the midst of loss, and dignity in failure is great poetic art ${ }^{17}$. Cúirt an Mhean Oiche adheres impeccably to this maxim. The eternal plight of the sexes, the constraints of marriage and the torment of unfulfilled lust and desire, are neither transient fashions nor fads of the moment. Irish-language drama, and those involved in its creation, production, and facilitation, know full well the benefit of finding beauty in sad empty halls and (in)dignity in failing to generate enough public interest to even stage a play. The text's attraction for de Fréine may have been that it afforded both a canonical text and established form to deal

a workshop led by Mercier called Bí ag Scríobh [Get Writing]. "It was amplifying our regular, unsolicited script process", says Howard. "Ramping it up and saying, "We are genuinely interested in engaging with Irish language playwriting, come show us what you have got." Caomhan Keane, "Irish language theatre - is it time to stage a revival?", Irish Times, 13 June 2011.

16. The cast comprised of Síle (Solweg Ní Fhiaich), Áine (Aoileann Ní Chonchubhair), Cáit (Róisín Nic an tSíthigh), Nóra (Gráinne Nic Fhirléinn), Jaimsí Mhichíl Liam (Lionel Mac Cárthaigh), Tomás Sheáinín (Colm Ó Broin), Peadar Sheosaimh Mhóir (Cathal Ó Murchú), Máirtín Bán (Aodh Ó Domhnaill), An Breitheamh (Eimear Ní Mhéalóid), An Báille (Fidelma Ní Ghallchobhair), Oifigeach Cúirte 1 (Tadhg Ó Conchubhair), Oifigeach Cúirte 2 (Lelia Ní Chinnéide). Produced by Fidelma Ní Ghallchobhair, costumes by Lelia Ní Chinnéide,and light and sound by Mike Donoghue.

17. David Mamet, "Attention Must Be Paid", New York Times, 13 February 2005. [http://www.nytimes. com/2005/02/13/opinion/13Mamet.html?_r=0] (accessed 16 March 2016). 
with social issues in a manner that was firmly established, sanctioned and familiar in both English and Irish ${ }^{18}$. Indeed in a recent interview in the Dublin Review of Books, she discloses that "Although not written by me, The Midnight Court is what kick-started my writing ${ }^{19 "}$.

Her first engagement as a creative writer with this canonical text, presumably, occurred when she adapted it in 1982 for collaboration with the Dublin Shakespeare Society. Coincidently, 1982 was a significant year for Merriman studies: it marked the publication of Cúirt an Mheon-Oíche, Liam P. Ó Murchús scholarly edition of the text, four separate reprints of various mid-twentieth-century English translations of the text by Percival Arland Ussher (1899-1980), Canon Coslett Ó Cuinn (1907-1995), Frank O'Connor (1903-1966) and Denis Woulfe's 1789 translation, in addition to an art exhibit by Portlaw-born artist John Verling (1943-2009) at the Caldwell Gallery, Cork. Whether related or not, de Fréine's first public involvement happened at a time when the text was circulating in twentieth-century public popular discourse rather than narrow academic spheres in Ireland ${ }^{20}$.

Several factors distinguish de Fréine's intervention. She is the sole woman writer to publish a translation and adaption of the poem; hers was the only one to reconfigure the poem's structure by manipulating the narrative voice to create a more conventional set of monologues. The original text, with its social commentary and dramatic plot twist at the conclusion, lends itself impeccably to modern theatre where we expect and indeed often demand, to witness, what Josipovici terms "the author's manipulation of plot to create exciting theatre, driving towards its (surprising and often unexpected) conclusion ${ }^{21}$ ". In the English-language Brian Merriman's The Midnight Court, translated and dramatized by Celia de Fréine, the foreword explains how the author decided "to explore its dramatic potential rather than reproduce it as a poem in English. To this end, I re-sequenced lines, and allocated some to newly-created characters: the wenches, the codgers and the fairy maiden $s^{22}$ ". In addition, rather than rehash the issue of "illegitimacy" in the same terms as Merriman, de Fréine expands and updates the debate by expanding and elaborating on the controversy to resonate more with contemporary readers and, in a Brechtian move, strips audiences of the safety and comfort of viewing this

18. For an overview of the critical reception of "Cúirt an Mhéan Oíche/The Midnight Court", see The Midnight Court / Cúirt an Mheán Oíche: A Critical Edition, ed. Brian Ó Conchubhair, Syracuse, NY, Syracuse University Press, 2011.

19. See Lia Mills, "Hidden Ireland", Dublin Review of Books, Issue 61, November 2014. [http://www.drb.ielessays/ hidden-irelands] (accessed 26 March 2016).

20. The poem had, of course, been a stable of Irish-language vernacular, manuscript and popular culture throughout the nineteenth century. See Liam Mac Peaircín, An eala ar a bhfuaid: Cúirt an Mheán Oíche i Lámha na Scriobhaithe, Dublin, Coiscéim, 2016.

21. Gabriel Josipovici, What Ever Happened to Modernism?, New Haven, Yale University Press, 2010, p. 153.

22. Celia de Fréine, Brian Merriman's The Midnight Court, Arlen House, 2012, p. 9. 
issue through the lens of history and humour and forcing them to face contemporary social controversies and irregularities.

This text, Brian Merriman's The Midnight Court, treats of the Court as it is in the act of being composed. In contrast to the two other texts that precede (Desire) Meanmarc) and follow (Plight/Cruachás) it details events as Merriman composes the "text"; that is, the play commences with Merriman having composed in Irish the opening lines before he rests and verbalizes his thoughts, in English, to the audience before falling asleep. When the character Merriman speaks, he does so in words and lines translated from the original poem. The two fairy maidens, introduced into the narrative by de Fréine, reduce the burden on the bailiff to convey information, provide context and background for the audience, and reduce the strict reliance on two monologues. Similarly the two codgers serve as male counterparts to the fairy maidens, and consequently break up the monologues while providing diversity and variety to the voice and narration ${ }^{23}$. This change, in turns, speeds up the narrative exchange, increases the intensity, and heightens the narrative tension. Such features are central in translating the text from a series of monologues to a conventional multi-actor play.

In keeping with the original, the text concludes with Aoibheall's speech. De Fréine's version differs in that "someday soon the priests will wed/Heed my advice; what is needed is patience: /a time will come with the Vatican's leave,/ when a seal will go on a Papal Bull;/the Cardinals will consider the country's woes/and having debated the issue, agree/to release forthwith these spancelled lads $s^{24}$ ". The "original" text as provided by Ó Murchú, is less conclusive and more ambiguous in anticipating a future time when the Pope may abandon the rules attending celibacy: "Seachain go fóill na comhachtaigh íogmhar/Is caithfid siad pósadh fós pé chífeas,/Tiocfaidh an lá le lánchead comhairle/Is cuirfidh an Pápa lámh na gcomhacht air, suífidh an chuideachta ar thubaist na dtíortha/Is scaoilfear chugaibh fá urchall cuibhrigh/Fiantas fola agus fothrom na feola/Is mian bhur dtoile, na tollairí teo seo ${ }^{25}$ ". The play ends, as the poem does, with the narrator awakening just as the women were about to punish him for his celibacy. This version follows the conventional dramatic adaptations of the poem in that it plays on the sexual humour and sexual complaints, remedies and desires of the various characters and achieves a boisterous humorous conclusion.

Desire / Meanmarc, the trilogy's first instalment, is arguably the richest and most historically nuanced of the three parts. A delight for anyone familiar with the original and its surrounding subplots, it displays a comprehensive and scholarly awareness and knowledge not only of the text but of the folklore, anecdotes, and

23. This version calls for thirteen actors, excluding musicians.

24. De Fréine, Brian Merriman's The Midnight Court, p. 53-54.

25. See Liam P. Ó Murchú, Cúirt An Mheon-Oíche, Dublin, An Clóchomhar, 2005, p. 43, lines 907-914. 
theories surrounding the text itself, the text's creation, and the creator's biography, all of which is imaginatively reinterpreted and reimagined in dramatic form with vividly conceived characters and finely calibrated dialogue which harps on, and harks back to, the original. This rich play demonstrates how an early-twenty-firstcentury writer can mine a rich lode of material to produce a play that interrogates social issues, gender relations, and class distinctions that cross the centuries and the decades. The play succeeds as a recreation of late-eighteenth-century rural Ireland with its attendant cultural and socio-economic tensions, while also critiquing the same issues in contemporary Ireland. Indeed, de Fréine's plays, while understandably lacking the original's shock factor and linguistic wealth, render Merriman relevant for twenty-first-century audiences, less in her dramatization of the poetic text than in her recalibration of the narrative focus to address the status and role of single mothers and children "born out of wedlock". This task she focuses on in Plight/Cruachás, the third instalment, in which she considers the social issues and concerns to be discussed were the imaginary court described in Cúirt an Mheán Oíche to be reconvened in early twenty-first century Ireland. The Lorg Merriman project rebounds and reverberates off a controversy surrounding the role and status of unmarried children and single mothers in Irish society. The text's charge is less concerned with sexual practices than with the social position of children and mothers. In attuning her text to foreground the role of mothers whose children were engendered out of traditional wedlock, the third de Fréine text draws on the uproar surrounding Kevin Myers' infamous 8 February 2005 Irish Times op-ed, known readily as his "Mothers of Bastards" article.

Myers, a controversial polemicist and provocative commentator with a deserved reputation as the chief challenger of Irish social orthodoxies, penned arguably - the decade's most incendiary article ${ }^{26}$, in which he endorsed comments about unmarried mothers attributed to Ed Walsh, former President of the University of Limerick (1989-98). Walsh, in the course of a lecture, allegedly claimed that the absence of fathers destabilizes society and linked children raised in singleparent families to violent crime, burglary, child abuse, truancy, rape, murder and social problems ${ }^{27}$. Myers, ever the controversialist and ever loyal to those mavericks whom he admired, attempted to defend Walsh and deride his detractors. Eager to run a polemic up the flag mast, he indiscriminately lumped together a variety of women - rape survivors, widows, divorcees - without using any sources and confidently asserted:

26. Ironically Myers had criticized Mary Ellen Synon's disparagement of the 2000 Sydney Paralympics on 22 October 2000 in the Irish Independent.

27. These claims where not specific to Ireland but rather indicators of what could be expected in Ireland in due course. 
...our system of benefits to unmarried mothers is creating a long-term time-bomb. Even as things stand, we are bribing the unmotivated, the confused, the backward, the lazy into making the worst career decision of their young lives, and becoming professional unmarried mothers, living off the State until the grave takes over. Our welfare system is creating benefits-addicted, fatherless families who will be raised in a culture of personal and economic apathy - and from such warped timber, true masts are seldom hewn.

Myers' article, published in the Irish Times, drew widespread condemnation, including from Nuala Fennell, a former Irish government minister of state for justice, the threat of libel and a demand for a retraction from fellow Irish Times columnist John Waters, and an extensive denunciation for its tone, attitude, and language. Myers' position became ever more untenable when Walsh, who had initiated the debate, criticized Myers. Soon afterwards Myers broke with the Irish Times and joined the more popular and populist Irish Independent. Despite being a watershed moment in Irish social history, it did not dispel the underlying issues. Writing four years later, in 2009, Niamh Ní Chearúil argued:

[...] blanket stereotyping of single parents - specifically lone mothers as scroungers who chose to live off the State is both an undeniable reality, and a shameful one. As a result of this stereotyping, which takes place in the media, in our print publications, and in the discourse of our public representatives, a thoroughly negative image of these people is concocted. This filters through to become a general attitude that society has adopted in relation to them... Once popularized through the media, these ideas take on the appearance of objective reality. It is all too possible to stigmatize and exclude a group in society with a negligible voice - they pose little opposition - so as to preserve the status quo, and maintain an economic system where no huge spending is made in social welfare ${ }^{28}$.

It is possible, if not probable, that this controversy informed de Fréine when writing in 2009. It certainly informed her audience's opinions as they approached her trilogy published in 2012. In her foreword to Brian Merriman's The Midnight Court, de Fréine claims that "It is almost certain also that he was the illegitimate son of a member of the gentry, raised by the stonemason his mother married ${ }^{29}$." In translating and dramatizing the poem, de Fréine had an opportunity to familiarize herself intimately with a text that addressed and spoke not only to eternal

28. Niamh Ní Chearúil, "The Negative Stereotyping of Lone Mothers”, Socheolas: Limerick Student Journal of Sociology, Vol. 2, 1, November 2009.

29. Celia de Fréine, Brian Merriman's The Midnight Court, p. 9. 
human concerns and preoccupations, but to work with and immerse herself in a text that offered a powerful corrective to the aforementioned controversy. De Fréine directly addressed the role and status of single unmarried mothers and their fatherless children in Irish society at the point when it was undergoing tectonic social change.

In Plight: Cruachás the issue of "bastard" children is addressed both by Áine, the main female plaintiff, and by the Judge. Áine relates Peig's incestuous rape by her unnamed rural uncle with whom she was sent to live during his wife's illness. Her modern day Aoibheall refers to such fatherless children in her summation:

As for insulting Peig's child I don't believe I heard the like In this court. The children Of this country are blessed, No matter how they were born. They have been brought into the world And it is up to you to rear them.
Agus, maidir le leanbh Pheig a mhaslú- Ni chreidim gur chuala mé a leithéid
Sa gcuirt seo. Is beannaithe iad
Gasuir na tíre seo, is cuma
Faoin gcaoi ar rugadh iad.
Tá siad tagtha ar an saol agus is füibhse Cúram a dtógála.

The bastard, writes Kingsley Davis, "like the prostitute, thief and beggar, belongs to that motley crowd of disreputable social types which society has generally resented, always endured. He is a living symbol of social irregularity ${ }^{30 ”}$. But the play's remit is broader and wider than that of the original. De Fréine's play catalogues the sexual and abuse scandals that circulate in public and popular discourse in late-twentieth and early twenty-first century Ireland. One criticism of the eighteenth-century text is that it falls away at the end without any major political and social statement and relies on the humour of the poet awakening from his hallucination just as a gaggle of women seek to strip and beat him for his lack of sexual activity. De Fréine's version recalls the original eighteenth-century poem, concluding as it began with Síle, the teacher, awakening in her urban classroom, reading her students' love poems, as she was at the outset, thus bringing closure and pattern to the play.

This adaptation of Merriman's text considers the sexual mores and dilemmas of an "ancient but recently discovered tribe" in Ireland. Less comedic than the eighteenth-century text, it is no less compelling in dealing with and debating issues of male sterility, low-sex drive, hand festivals, pornography, rape, violence and abuse within relationships and marriage, incest and child abuse. This version is far more than an updated Midnight Court in raising and addressing the "New Irish", and homosexuality. Indeed, it is closer to Maireád Ní Ghráda’s An Triail in

30. Kingsley Davis, "Illegitimacy and the social structure", W. J. Goode, ed. Readings on the Family and Society, Englewood Cliffs, NJ, Prentice Hall, 1964, p. 21. 
that the audience is positioned as participants and actors in the social structure by removing the fourth wall ${ }^{31}$.

In Merriman's original text, the narrator-poet is the accused and the object of the complaints is the main focus. In contrast De Fréine's version directly challenges audiences to consider their participation in the social conditions that sustain the matters raised in the play. However, unlike the eighteenth-century text that closes humorously, de Fréine closes by posing a question for the audience: what roles should educators, teachers, and influential adults play in the lives of women such as those featured in the play? De Fréine avoids the cheap laugh and light entertainment, which a simple reading of Cúirt an Mheán Oiche offers to even the most limited actor, director and teacher. In replacing the male poet with a female teacher and setting it in a school - the site of socialization - de Fréine not only empowers women as stakeholders but as influential social partners. It raises the stakes and the onus directed at the audience to respond to the questions posed in the play. The ancient tribe, as presented in the play, is sufficiently vague that it allows for it to be read as any ethnic minority or social group - Irish Travellers, the "New Irish", etc., etc. ${ }^{32}$.

Like I was saying, all that I am is a teacher, Employed to teach literacy And numeracy and social skills To the oldest tribe in the country And what can I myself do To improve the situation Me that has no wish to poke my nose Into matters that are of no concern to me When all that I am is a teacher?
Faoi mar a bhi me ag rá, níl ionam Ach muinteoir a fostaiodh le litearthacht Is uimhearthacht is scileanna soisialta A theagasc don treibh is arsa sa tir. Agus ceard is féidir liomsa a dhéanamh Le feabhas a chur ar an scéal Mise nach bhfuil ag iarraidh mo ladar A chur i meadar gan suaitheadh, Mise nach bhfuil ionam ach múinteoir?

In this closing section, de Fréine introduces a reflexive note, absent from the original and from most if not all similar adaptations and translations. The issues of rape, incest and arranged marriages all feature in this version which borrows the original poem's scaffolding and imagery to construct a discussion of contemporary marriage, relationships and sexual practices for young women in contemporary Ireland.

De Fréine's literary sources and imaginative forefathers and foremothers are many and diverse. Her plays fit neither nicely nor linearly into existing patterns or into distinct literary histories and lineages. They are, in some traditional Irish-lan-

31. Merriman's original audience may well have recognized names and references in the text or versions of it.

32. De Fréine spent several years as a literacy teacher with the Travelling community. See Lia Mills, "Hidden Ireland”, Dublin Review of Books, Issue 61, November 2014. [http://www.drb.ielessays/hidden-irelands] (accessed 26 March 2016). 
guage dramatic respects, illegitimate "bastard" plays: reworked, rewritten, adaptations and foreign plays belonging neither fully nor clearly to the Irish-language dramatic tradition. But they enrich and enhance that tradition and are welcome and valuable additions regardless of who their imaginative fathers - or mothers - were, or might have been. Behind the linguistic curtain, contemporary Irishlanguage theatre is addressing some very real anxieties and resentments and offering a window on contemporary global culture and social issues. These "bastard" plays may be uncertain of their historic and literary roots, but they belong to all audiences and demand our attention. Above all they are an appropriate comment on social issues in the Irish Republic and bring to fore the treatment of single mothers, "illegitimacy" and conservative ideologies that seek to discriminate against the weak and vulnerable in society. Such issues and ideologies seem perverse in an Irish Republic that in 2016 celebrated the 1916 rebellion and the proclamation that guaranteed religious and civil liberty, equal rights and equal opportunities to all its citizens, and declares its resolve to pursue the happiness and prosperity of the whole nation and of all its parts, cherishing all of the children of the nation equally, and oblivious to the differences carefully fostered by an alien Government, which have divided a minority from the majority in the past. 